\title{
Effect of Somatostatin on Metabolic and Hormonal Changes Induced by Nicotinic Acid in Insulin-Dependent Diabetics*
}

\author{
A. S. Luyckx and P. J. Lefebvre \\ Division of Diabetes, Institute of Medicine, University of Liège, Liège, Belgium
}

Summary. The study investigated the respective influences of nicotinic acid and somatostatin on plasma concentrations of blood glucose, free fatty acids, glucagon, growth hormone and cortisol in insulin-dependent diabetic subjects. After administration of nicotinic acid alone, marked depression of plasma FFA was accompanied by significant increases of plasma glucagon, growth hormone and cortisol. The glucagon and growth hormone responses to nicotinic acid were significantly reduced when plasma FFA were raised by intravenous administration of heparin and triglycerides. Somatostatin alone induced a significant decrease in blood glucose, plasma glucagon and growth hormone concentrations. Plasma FFA remained unchanged. Somatostatin did not modify the nicotinic acid-induced fall in plasma FFA, but completely blocked the corresponding increments in glucagon and growth hormone. The cortisol rise was not altered by somatostatin. Rebound of glucagon and growth hormone levels were seen upon discontinuation of the somatostatin administration. These results demonstrate that the plasma FFA concentration plays a role in the regulation of glucagon and growth hormone secretion in insulin-dependent diabetics. Furthermore, they indicate that somatostatin, previously shown to be capable of negating the stimulatory effect of various factors on glucagon and growth hormone secretion, also affects the response of these hormones to FFA depression.

Key words: Somatostatin, nicotinic acid, insulin-dependent diabetes, glucose, free fatty acids, glucagon, growth hormone, cortisol, heparin, triglycerides.

\footnotetext{
* Presented at the 11th Annual Meeting of the European Association for the Study of Diabetes, Munich, Sept. 1975, and published in abstract form in Diabetologia, 1975, 11, 360.
}

Somatostatin depresses basal levels of glucagon $[1,6$, 9] and growth hormone [34] as well as the responses of both hormones to arginine infusion $[11,26]$, insulininduced hypoglycemia [5, 26], L-Dopa [20] and epinephrine $[19,33]$. An acute decrease in plasma free fatty acid (FFA) concentration also stimulates glucagon $[2,12,23]$ as well as growth hormone [review in 8] secretion under various experimental conditions, as well as in normal man. The present investigation aimed at evaluating the influence of a fall in plasma FFA, induced by nicotinic acid (NA), on glucagon and growth hormone secretion in insulin-dependent diabetic subjects. After having established the stimulatory role of nicotinic acid on both hormones, we tested the influence of somatostatin on the metabolic and hormonal responses to nicotinic acid. An increase in plasma cortisol was recently observed during nicotinic acid infusion in normal man [27]; for this reason, variations in plasma cortisol were also determined in the present study

\section{Material and Methods}

\section{Subjects}

Informed consent was obtained from sixteen insulindependent diabetic subjects. All patients were hospitalized in the Metabolic Unit of our Institution several days before in order to initiate insulin therapy or to improve the degree of control by changing the dosage or type of insulin administered. The duration of known diabetes thus varied from a few days (3 cases) up to 20 years. All cases were free from acute illness or ketosis at the time of the study. Age, sex, height and weight characteristics are given in Table 1 . 
Table 1. Characteristics of the subjects studied

\begin{tabular}{llllll}
\hline & $\begin{array}{l}\text { Case } \\
\text { number }\end{array}$ & Scx & $\begin{array}{l}\text { Age } \\
\text { (yrs) }\end{array}$ & $\begin{array}{l}\text { Height } \\
(\mathrm{cm})\end{array}$ & $\begin{array}{l}\text { Weight } \\
(\mathrm{kg})\end{array}$ \\
\hline & 1 & M & 18 & 175 & 65 \\
& 2 & M & 54 & 162 & 57 \\
& 3 & M & 45 & 169 & 74 \\
Studies & 4 & M & 52 & 176 & 80 \\
I and II & 5 & M & 52 & 180 & 79 \\
& 7 & M & 40 & 170 & 59 \\
& 8 & M & 58 & 166 & 55 \\
& 9 & M & 34 & 160 & 80 \\
& 10 & M & 23 & 165 & 55 \\
& 11 & F & 54 & 168 & 63 \\
Studies & 12 & M & 53 & 170 & 74 \\
I and III & 13 & F & 43 & 163 & 67 \\
& 14 & M & 56 & 174 & 60 \\
& 15 & M & 18 & 188 & 68 \\
& 16 & M & 32 & 179 & 79 \\
\hline
\end{tabular}

Table 2. Basal values of the various parameters in studies I and II $(\mathrm{m} \pm \mathrm{SEM}, \mathrm{n}=9)$

\begin{tabular}{lcc}
\hline & $\begin{array}{l}\text { Study I } \\
(\mathrm{n}=9)\end{array}$ & $\begin{array}{l}\text { Study II } \\
(\mathrm{n}=9)\end{array}$ \\
\hline $\begin{array}{l}\text { Blood glucose } \\
\mathrm{mg} / 100 \mathrm{ml}\end{array}$ & $238 \pm 38$ & $227 \pm 30$ \\
$\begin{array}{l}\text { Plasma FFA } \\
\mu \mathrm{Eq} / 1\end{array}$ & $686 \pm 69$ & $718 \pm 51$ \\
$\begin{array}{l}\text { Plasma glucagon } \\
\text { pg/ml }\end{array}$ & $92 \pm 34$ & $77 \pm 26$ \\
$\begin{array}{l}\text { Plasma growth hormone } \\
\text { ng/ml }\end{array}$ & $2.7 \pm 1.0$ & $2.7 \pm 0.7$ \\
$\begin{array}{l}\text { Plasma cortisol } \\
\mu \mathrm{g} / 100 \mathrm{ml}\end{array}$ & $10.2 \pm 1.2$ & $9.9 \pm 1.4$ \\
\hline
\end{tabular}

\section{Experimental Protocols}

All studies were performed during the morning between 9 and 11 a. m. after an overnight fast. Insulin therapy was omitted on the morning of the test; thus, the last insulin injection was given about 26 or 14 hours before the test, depending on the kind of insulin régime.

Three protocols, the details of which are given in Figure 1, were utilized: Study I: infusion of NA alone; Study II: infusion of NA after and during an infusion of SRIF; Study III: infusion of NA after and during an infusion of triglycerides preceded by $\mathrm{I}$. V. administration of $5000 \mathrm{U}$ heparin. Two tests were performed on each subject on two different days: studies I and II in 9 cases and studies I and III in 7 other cases. The order in which the two tests were performed alternated between patients and the interval between both tests in a given patient was between 2 and 5 days.
Assays

Blood glucose was determined by the method of Hoffman [15] adapted to the Technicon Auto Analyzer, plasma FFA according to Dole and Meinertz [7], plasma glucagon according to Luyckx [22], using antiserum $30 \mathrm{~K}$ kindly supplied by Dr. R. H. Unger, plasma growth hormone according to Franchimont and Burger [8] and plasma cortisol according to Leclercq [18].

Statistical analysis of the results was carried out by calculating the Student's $t$ test for paired and non paired values according to Snedecor [31].

\section{Results}

Basal values. Paired comparison between the mean basal values of all parameters failed to reveal any statistically significant difference between Study I and II (Table 2).

Blood glucose remained essentially unchanged during the periods of saline and nicotinic acid infusion of Study I (Fig. 2). In study II, SRIF induced a progressive decline of blood glucose. Paired comparison with the zero time value showed that the fall in blood glucose was already significant at $10 \mathrm{~min}(\mathrm{p}<0.025)$ and was maximal $(32 \mathrm{mg} / 100 \mathrm{ml}$, or $14 \%$ of the basal value, $p<0.005$ ) at the end of the SRIF infusion (Fig. 2). An immediate increase in blood glucose occurred when the SRIF infusion was stopped at the 75 th min. Plasma free fatty acid levels were stable before the beginning of nicotinic acid administration in study $I$ as well as in study II. SRIF per se did not affect plasma FFA concentrations. In both tests, nicotinic acid induced a marked and sustained depression of plasma FFA. No significant difference was found between the plasma FFA values obtained in test I and test II (Fig. 3).

Plasma glucagon exhibited a significant rise during the first 60 min of nicotinic acid administration. Compared with the $30 \mathrm{~min}$ value, the mean glucagon levels increased by $+25.5 \mathrm{pg} / \mathrm{ml}( \pm 7.2 \mathrm{SEM} ; \mathrm{p}<0.01)$ at $\mathrm{T}=45$ and $+26.7 \mathrm{pg} / \mathrm{ml}( \pm 5.2 \mathrm{SEM} ; \mathrm{p}<0.001)$ at $\mathrm{T}=60$ (Fig. 4).

In study II, administration of SRIF alone significantly depressed plasma glucagon and completely blocked the glucagon rise induced by nicotinic acid. Cessation of the SRIF infusion resulted in an immediate and significant rebound in plasma glucagon.

\section{Growth Hormone}

In study $\mathrm{I}$, a slight and not significant rise was recorded between 0 and $30 \mathrm{~min}$. Thereafter, nicotinic acid in- 


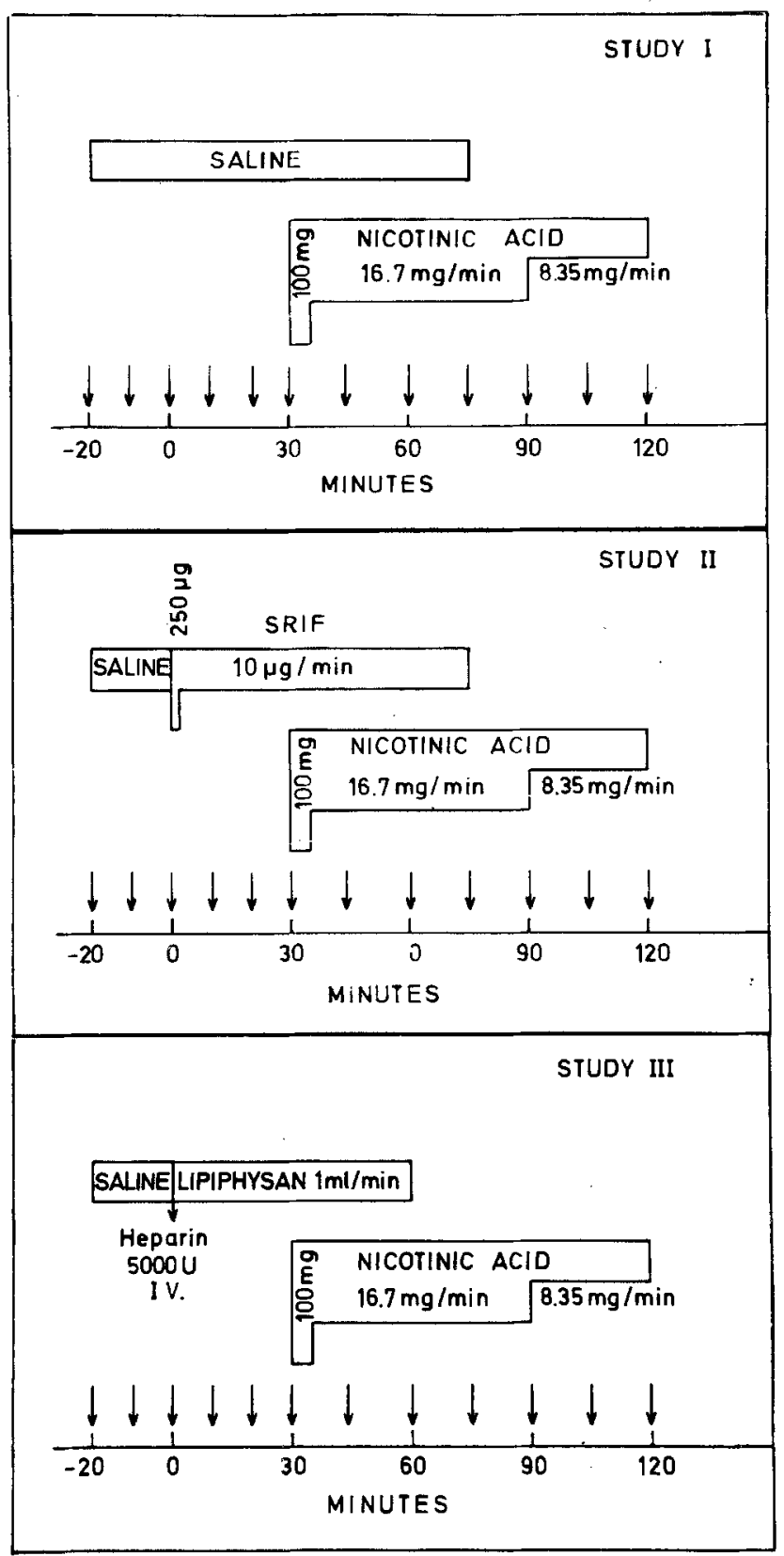

Fig. 1. Experimental protocol of studies I, II and III

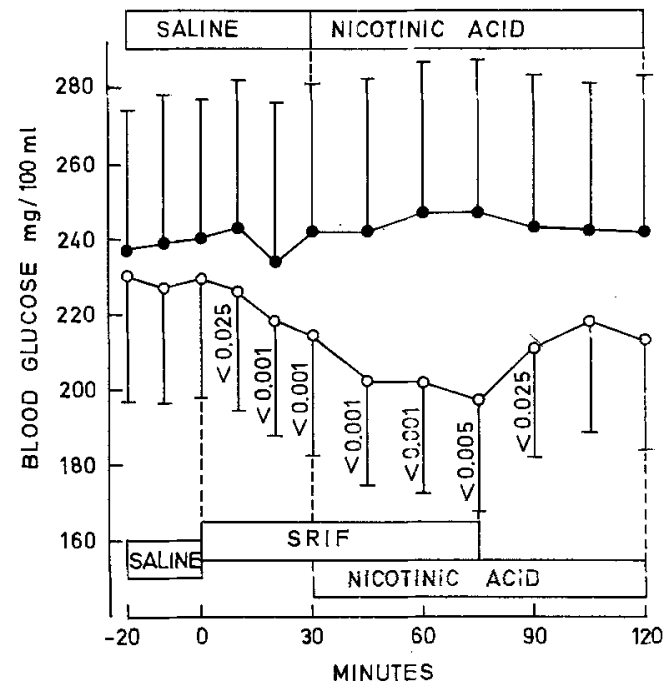

Fig. 2. Evolution of blood glucose in study $\mathrm{I}(\bullet-\bullet)$ and II $(\circlearrowleft-0)$. Results are expressed as mean \pm standard error of the mean $(\mathrm{m} \pm$ SEM). Number of subjects (n): 9. The statistical significance indicated along SEM corresponds to the value of $p$ for paired comparison with the zero time value

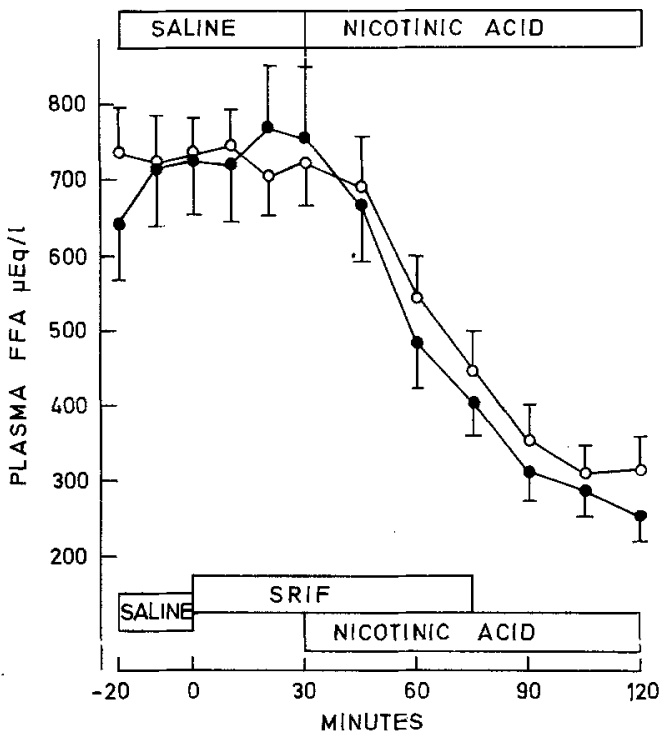

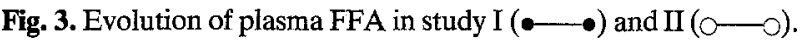
Results are expressed as $m \pm S E M, n=9$

\section{Plasma Cortisol}

It is known that plasma cortisol follows nycthemeral variations and decreases spontaneously during the morning hours. Quantitative evaluation of this phenomenon was obtained by measuring plasma cortisol between 9 and 11 a. m. in eight saline-infused, insulin-dependent diabetics (shaded area in Fig. 6). crease in plasma $\mathrm{GH}$ occurred upon cessation of the SRIF infusion. value found significant by paired comparison with the 30 min value was at $\mathrm{T}=60$ (Fig. 5). SRIF not only depressed the basal $\mathrm{GH}$ value by more than $50 \%$, but also abolished the stimulatory effect of nicotinic acid. As already observed for glucagon, an immediate in- 


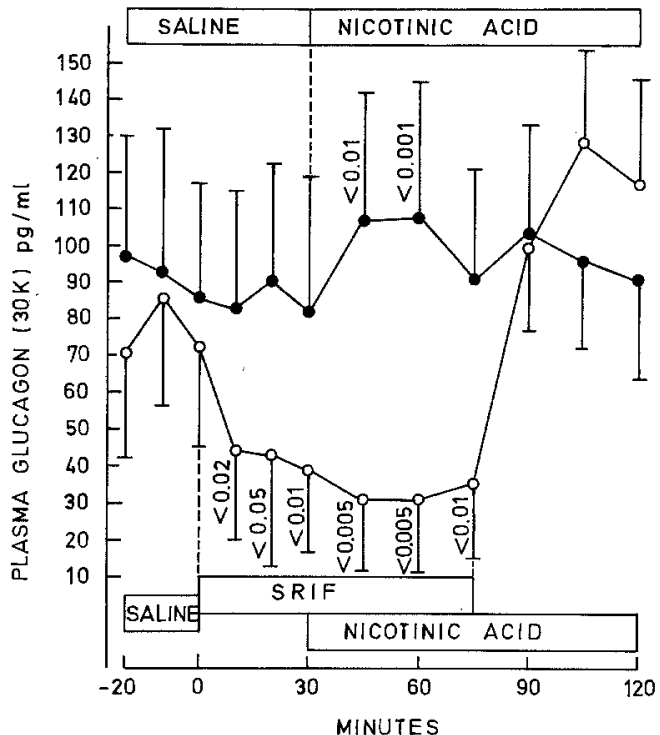

Fig. 4. Evolution of plasma glucagon in study I (•—-) and II $(0-0)$. Results are expressed as $\mathrm{m}=\mathrm{SEM}, \mathrm{n}=9$. Values of $p$ indicated along SEM correspond to paired comparison with the 30 min value for study I and with the zero time value for study II
The decline in plasma cortisol between $\mathrm{T}-20 \mathrm{~min}$ and $\mathrm{T}+30 \mathrm{~min}$ in studies I and II was similar to that seen in these control conditions. Infusion of NA resulted in a significant increase in plasma cortisol both in the absence and in the presence of the somatostatin infusion (Fig. 6).

\section{Influence of an Elevated FFA Level on the Response to Nicotinic Acid}

A series of seven additional patients were submitted to study I. Here again, infusion of NA resulted in a decrease in plasma FFA associated with an increase in plasma cortisol, glucagon and growth hormone (Fig. 7).

Administration of heparin and triglycerides provoked a sharp rise in plasma FFA levels which remained between 2500 and $1800 \mu \mathrm{Eq} / 1$ during the period of infusion. During this period, the glucagon and growth hormone rises in response to NA were significantly reduced. The cortisol increase was reduced but the difference was not statistically significant (Fig. 7).

\section{Clinical Tolerance}

No obvious side effect due to somatostatin was observed in the nine patients. In all patients, the onset of the NA infusion was accompanied by the characteristic "flush" produced by the vasodilating action of this

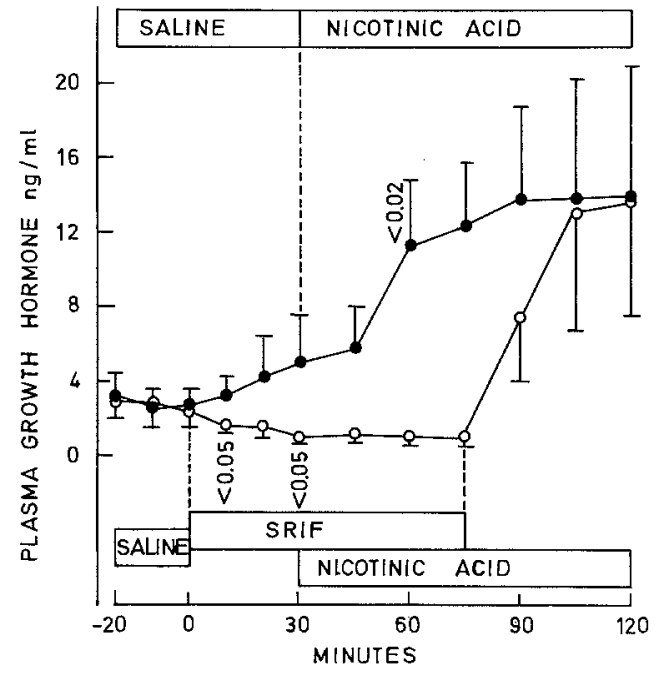

Fig. 5. Evolution of plasma growth hormonc in study $I(\bullet-\bullet)$ and II $(\bigcirc-O)$. Results are expressed as $\mathrm{m} \pm \mathrm{SEM}, \mathrm{n}=9$. Values of $p$ indicated along SEM correspond to paired comparison with the 30 min value for study I and with the zero time valuc for study II

drug. This was occasionally associated with a transient feeling of chest discomfort. These symptoms progressively disappeared despite the continuation of NA infusion.

\section{Discussion}

\section{Effect of Somatostatin on Basal Values}

In the present series, the mean basal plasma glucagon concentration found in insulin-dependent diabetics $(93 \mathrm{pg} / \mathrm{ml} \pm 15, \mathrm{SEM}, \mathbf{n}=32$ ) was slightly, but not significantly, higher than the one found in normal controls $(65 \mathrm{pg} / \mathrm{ml} \pm 8$, SEM, $\mathrm{n}=23)$. Contrasting with some earlier studies [11], this lack of difference is however in agreement with other reports [25, 29]. Somatostatin depressed plasma glucagon by $50 \%$ and a $14 \%$ decline in blood sugar was concomitantly observed, suggesting the participation of glucagon in the hyperglycaemia of these subjects [28]. Lack of change in plasma FFA during somatostatin administration suggests that lipolysis is not affected by either somatostatin or glucagon in these basal conditions. It thus appears likely than the increase in plasma FFA appearing after somatostatin administration in normal subjects and in non-insulin-dependent diabetics is mediated through a reduction in plasma insulin. [6, $24,26]$. 


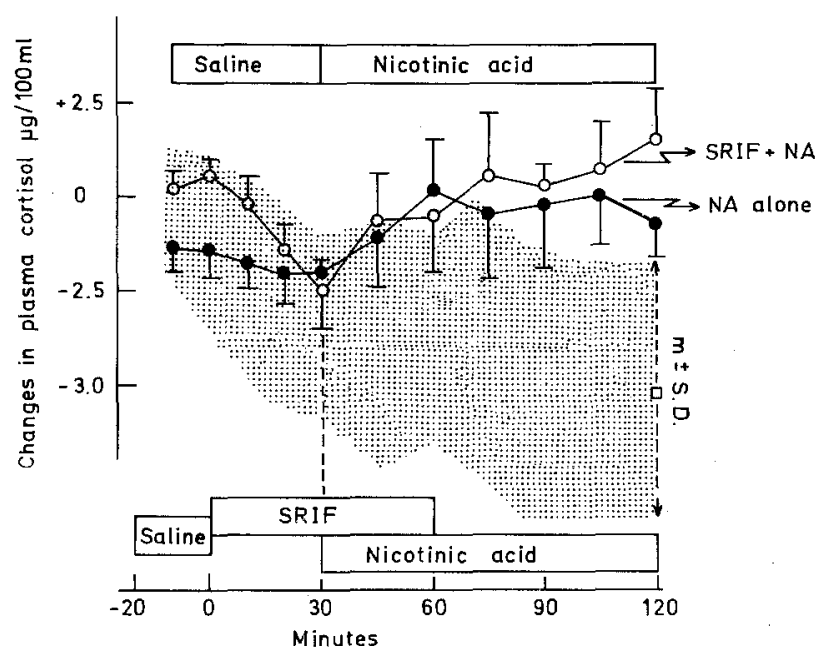

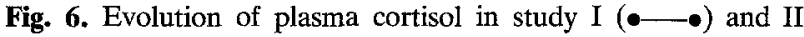
$(\bigcirc \bigcirc)$. Results are expressed as $m \pm S E M, n=9$. The shaded area corresponds to the mean changes in plasma cortisol ( \pm one $S$. D.) observed in 8 insulin-dependent diabetic subjects infused with saline during the same period of time
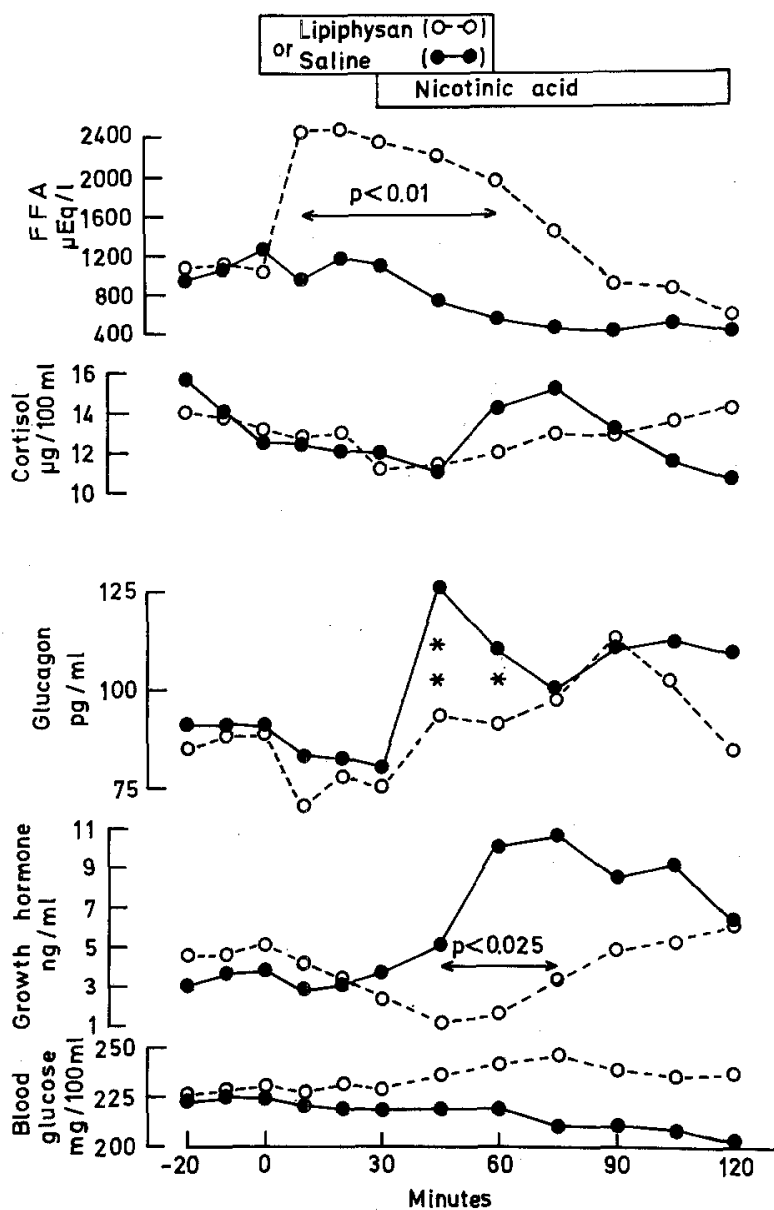

Fig. 7. Comparison of blood glucose, plasma FFA, glucagon, growth hormone and cortisol concentrations in seven insulin-dependent diabetics after administration of nicotinic acid alone $(\bullet-\bullet)$ or during a triglyceride infusion $\left(\mathrm{O}^{-}--\mathrm{O}\right)$. Heparin $(5000 \mathrm{U})$ was injected I. V. immediately before starting the infusion of triglyceride. ${ }^{*} \mathrm{p}<0.025 ; * * \mathrm{p}<0.005$

\section{Effect of Nicotinic Acid Infusion}

Infusion of nicotinic acid alone depresses plasma FFA. Recent data in normal man strongly suggest that this fall in plasma FFA is responsible for a complex response of lipolytic hormones including an early rise in plasma glucagon and a late increase in $\mathrm{ACTH} /$ cortisol and growth hormone [27]. Quantitatively, the rise in plasma glucagon after 30 min does not differ significantly between normal subjects $(+41.2 \mathrm{pg} / \mathrm{ml}$ $\pm 4.1, \mathrm{SEM}, \mathrm{n}=23$ ) and both groups of insulin-dependent diabetics $(+28.7 \mathrm{pg} / \mathrm{ml} \pm 6.5$, SEM, $\mathrm{n}=$ 16). These observations further substantiate the concept that plasma FFA levels regulate glucagon $[2,12$, 23] and growth hormone [8] secretion in man as well as in animals. Plasma corticosterone increased in rats following FFA depression [16], but an unequivocal elevation in plasma cortisol was not seen in normal humans [17], probably because the duration of the NA infusion in this study was too short. The rise in plasma glucagon, growth hormone and cortisol observed during nicotinic acid infusion in our study supports the view that plasma FFA levels play a role in the control of the secretion of these hormones in diabetics. One could, however, argue that the hormonal changes were due, not to FFA depression, but rather to another direct or indirect effect of NA. This was suggested by Andrews et al. (1975) in normal subjects. However, the fact that, in diabetics, the stimulant action of NA. on glucagon and growth hormone secretion was markedly reduced when plasma FFA were raised by heparin and triglycerides infusion, strongly argues against this interpretation.

\section{Influence of Somatostatin on the Effects of Nicotinic Acid}

Restricting the discussion to diabetic subjects, it was found that somatostatin reduced basal glucagon secretion as well as the secretory stimulation caused by arginine infusion [3, 11], insulin-induced hypoglycaemia [3] or ingestion of a protein meal [10]. Our results, demonstrating that SRIF also inhibits stimulation of the $\mathrm{A}_{2}$-cells by FFA depression, suggest that this hypothalamic hormone can be regarded as an universally active inhibitor of glucagon secretion, capable of reducing the relative or absolute glucagon excess demonstrated in diabetic subjects [32]. Growth hormone secretion is inhibited by somatostatin in basal conditions $[3,34]$ and after stimulation by exercise [14], insulin-induced hypoglycaemia $[3,13,26]$, arginine infusion $[3,24,26,30]$ levodopa $[20,30], \mathrm{PGE}_{1}$ [4] and, according to our results, also by FFA depression. The interest of such an inhibition in the prevention of diabetic microangiopathy has been discussed recently [21]. 
Our results demonstrated that the nicotinic acidevoked rise in plasma cortisol persisted during administration of somatostatin. This observation is in good agreement with the finding that the rise in plasma ACTH and cortisol provoked by insulin-induced hypoglycaemia persisted in baboons infused with somatostatin [5] and that SRIF-induced hypoglycaemia was accompanied by a rise in plasma cortisol in one case of glucagon-secreting tumour [24].

\section{The Post-Somatostatin Phase}

The hormonal effects of somatostatin were immediately reversible; indeed, fifteen to thirty minutes after discontinuation of SRIF infusion, hormone levels had already reached values similar to those found after stimulation with nicotinic acid alone. Whether this is due to a non-specific rebound phenomenon, or is the result of removing the inhibition of the hormonal response to FFA depression, cannot be decided on the basis of our results. The short-lived action of somatostatin is, besides its lack of specificity for glucagon and/or growth hormone secretion, the major obstacle to converting a remarkable tool in pathophysiological studies into a promising agent in the therapy of diabetes.

Acknowledgments. We are indebted to Dr Husson (Roussel Uclaf, Paris) for the generous gift of somatostatin, to Dr R. H. Unger (Dallas) for the supply of $30 \mathrm{~K}$ antiserum, to Dr Genard for the assays of cortisol, to Mrs Cartenstadt, Mr and Mrs Lallemand and Miss Rombaux for their skilled technical assistance, to $\mathrm{D}$. Binder for linguistic assistance and to Mrs Vaessen-Petit for secretarial help. This work was supported by the Fonds de la Recherche Scientifique Médicale Belge.

\section{References}

1. Alford, F. P., Bloom, S. R., Nabarro, J. D. N., Hall, R., Besser, G. M., Coy, D. H., Kastin, A. J., Schally, A. V.: Glucagon control of fasting glucose in man. Lancet 1974 II, 974-976

2. Andrews, S. S., Lopez, S. A., Blackard, W. G.: Effect of lipids on glucagon secretion in man. Metabolism 24, 35-44 (1975)

3. Assan, R., Basdevant, A., Heuclin, C., Selmi, A., Husson, J. C., Girard, J. R.: Effect on circulating hormones and fuels of acute somatostatin administration in insulin-dependent diabetic patients. (In preparation)

4. Bryce, D. B. S., Ych, M., Funderburk, C., Todd, H., Hertelendy, F.: Studies on growth hormone secretion. VII. Effects of somatostatin on plasma $\mathrm{GH}$, insulin, and glucagon in sheep. Diabetes 24, 842-850 (1975)

5. Chideckel, E. W., Palmer, J., Koerker, D. J., Ensinck, J., Davidson, M. B., Goodner, C. J.: Somatostatin blockade of acute and chronic stimuli of the endocrine pancreas and the consequences of this blockade on glucose homeostasis. J. clin. Invest. $\mathbf{5 5}$, 754-762 (1975)
6. Christensen, S. E., Hansen, A. A. P., Iversen, J., Lundbaek, K., Orskov, H., Seyer-Hansen, K.: Somatostatin as a tool in studies of basal carbohydrate and lipid metabolism in man: Modifications of glucagon and insulin release. Scand. J. clin. Lab. Invest. 34, 321-325 (1974)

7. Dole, V. P., Meinertz, H.: Microdetermination of long chain fatty acids in plasma and tissues. J. biol. Chem. 235, 2595-2599 (1960)

8. Franchimont, P., Burger, H.: Human growth hormone and gonadotrophins in health and disease. Amsterdam: North-Holland Publishing Company, New York: Oxford and American Elsevier Publishing Company Inc. 1975

9. Gerich, J. E., Lorenzi, M., Hane, S., Gustafson, G., Guillemin, R., Forsham, P. H.: Evidence for a physiologic role of pancreatic glucagon in human glucose homeostasis: Studies with somatostatin. Metabolism 24, 175-182 (1975)

10. Gerich, J. E., Lorenzi, M., Schneider, V., Karam, J. H., Rivier, J., Guillemin, R., Forsham, P. H.: Effect of somatostatin on plasma glucose and glucagon levels in human diabetes mellitus. New Engl. J. Med. 291, 544-547 (1974)

11. Gerich, J. E., Lorenzi, M., Schneider, V., Kwan, C. W., Karam, J. H., Guillemin, R., Forsham, P. H.: Inhibition of pancreatic glucagon responses to arginine by somatostatin in normal man and in insulin-dependent diabetics. Diabetes 23, 876-880 (1974)

12. Gerich, J. E., Langlois, M., Schneider, V., Karam, J. H., Noacco, C.: Effects of alterations of plasma free fatty acid levels on pancreatic glucagon secretion in man. J. clin. Invest. 53, 1284-1289 (1974)

13. Hall, R., Schally, A. V., Evered, D., Kastin, A. J., Mortimer, C. H., Tunbridge, W. M. G., Besser, G. M., Coy, D. H., Goldie, D. J., Mc Neilly, A. S., Phenekos, C. C., Wightman, D.: Action of growth hormone-release inhibitory hormone in healthy men and in acromegaly. Lancet 1973 II, 581-584

14. Hansen, A. P., Orskov, H., Seyer-Hlansen, K., Lundbaek, K.: Some actions of growth hormone release inhibiting factor. Brit. med. J. 1973 III, 523-524

15. Hoffman, W. S.: A rapid photoclectric method for determination of glucose in blood and urine. J. biol. Chem. 120, 51-55 (1937)

16. Johnson, W. J.: Stimulation of adrenocortical secretion by nicotinic acid and certain of its derivatives and analogues. Biochem. med. 2, 438-447 (1969)

17. Kagedal, B., Laurell, S., Rerup, C., Thorell, J.: Effect of nicotinic-acid-induced variation of plasma free fatty acids on some hormones in starving subjects. Scand. J. clin. Invest. 31, 331-336 (1973)

18. Leclercq, R.: Le dosage par compétition du cortisol plasmatique. Rev. Franç. Etud. clin. Biol. 14, 815-819 (1969)

19. Lorenzi, M., Karam, J. H., Schneider, V., Gustafson, G., Horita, S., Gerich, J. E.: Effect of somatostatin on plasma glucose, free fatty acids and glucagon responses to epinephrine in human diabetes. Clin. Res. 23 (Abstr.), 112 A, (1975)

20. Lovinger, R., Boryczka, A. T., Shackelford, R., Kaplan, S. L., Ganong, W. F, Grumbach, M. M.: Effect of synthetic somatotropin release inhibiting factor on the increase in plasma growth hormone elicited by L-Dopa in the dog. Endocrinology 95 , 943-946 (1974)

21. Luft, R., Guillemin, R.: Growth hormone and diabetes in man. Diabetes 23, 783-787 (1974)

22. Luyckx, A. S.: Immunoassays for glucagon. In: Glucagon. Molecular physiology, clinical and therapeutic implications. (eds. P. J. Lefebvre, R. H. Unger, pp. 285-298. Oxford: Pergamon Press 1972

23. Luyckx, A. S., Lefebvre, P. J.: Arguments for a regulation of pancreatic glucagon secretion by circulating plasma free fatty acids. Proc. Soc. exp. Biol. (N. Y.) 133, 524-528 (1970) 
24. Mortimer, C. H., Carr, D., Lind, T., Bloom, S. R., Mallinson, C. N., Schally, A. V., Tunbridge, W. M. G., Yeomans, L. Coy, D. H., Kastin, A., Besser, G. M., Hall, R.: Effects of growth hormone release inhibiting hormone on circulating glucagon, insulin and growth hormone in normal, diabetic, acromegalic and hypopituitary patients. Lancet 1974 I, 697-701

25. Ohneda, A., Ishii, S., Horigome, K., Yamagata, S.: Glucagon response to arginine after treatment of diabetes mellitus. Diabetes 24, 811-819 (1975)

26. Peracchi, M., Reschini, E., Cantalamessa, L., Giustina, G., Cavagnini, M., Pinto, M., Bulgheroni, P.: Effect of somatostatin on blood glucose, plasma growth hormone, insulin and free fatty acids in normal subjects and acromegalic patients. Metabolism 23, 1009-1015 (1974)

27. Quabbe, H. J., Ramek, W., L'Age, M., Luyckx, A. S.: Hormonal response to depression of free fatty acids (hGH, cortisol, insulin, glucagon) and the effect of glucose infusion. (Submitted to J. clin. Endocr.)

28. Sakurai, H., Dobbs, R., Unger, R. H.: Somatostatin-induced changes in insulin and glucagon secretion in normal and diabetic dogs. J. clin. Invest. 54, 1395-1402 (1974)

29. Schade, D. S., Eaton, R. P.: Modulation of fatty acid metabolism by glucagon in man. II. Effects in insulin-deficient diabetics. Diabetes 24, 510-515 (1975)
30. Siler, T. M., Vandenberg, G., Yen, S. S. C., Brazeau, P., Vale, W., Guillemin, R.: Inhibition of growth hormone release in humans by somatostatin. J. clin. Endocr. 37, 632-634 (1973)

31. Snedecor, G. W.: Statistical methods. 5th edition. Ames, Iowa The Iowa State University Press 1966

32. Unger, R. H., Orci, L.: The essential role of glucagon in the pathogenesis of diabetes mellitus. Lancet 1975 I, 14-16

33. Weir, G. C., Knowlton, S. D., Martin, D. B.: Somatostatin inhibition of epinephrine-induced glucagon secretion. Endocrinology 95, 1744-1746 (1974)

34. Yen, S. S. C., Siler, T. M., Devane, G. W.: Effect of somatostatin in patients with acromegaly. Suppression of growth hormone, prolactin, insulin and glucose levels. New Engl. J. med 290, 935-938 (1974)

Received: November 10,1975, and in revised form: June 16, 1976

Dr. A. S. Luyckx

Institut de Médecine

Hôpital de Bavière

Boulevard de la Constitution 66

$B-4000$ Liège

Belgium 